\title{
Maximising data and precision from detrital zircon U-Pb analysis by LA-ICPMS: The use of core-rim ages and the single-analysis concordia age
}

\author{
Sebastian Zimmermann ${ }^{\mathrm{a}, \mathrm{b}, *}$, Chris Mark $^{\mathrm{c}}$, David Chew ${ }^{\mathrm{c}}$, Peter J. Voice ${ }^{\mathrm{d}}$ \\ a iCRAG @ School of Earth Sciences, University College Dublin, Dublin 4, Ireland \\ b Department of Earth Sciences, Royal Holloway University of London, TW20 OEX Egham, UK \\ c iCRAG @ Department of Geology, School of Natural Sciences, Trinity College Dublin, Dublin 2, Ireland \\ d Department of Geosciences, Western Michigan University, Kalamazoo, MI 49008-5241, USA
}

\section{A R T I C L E I N F O}

\section{Article history:}

Received 6 June 2017

Received in revised form 14 December 2017

Accepted 18 December 2017

Available online $\mathrm{xxxx}$

\section{Keywords:}

$\mathrm{U} / \mathrm{Pb}$ detrital zircon dating

Single-grain concordia ages

Discordance filters

LA-ICPMS

\begin{abstract}
A B S T R A C T
$\mathrm{U}-\mathrm{Pb}$ detrital zircon geochronology is a powerful and well-established tool in provenance studies. Modern analytical techniques (particularly LA-ICPMS) increasingly facilitate the rapid acquisition of large datasets. While improvements in data handling approaches have been explored in detail (e.g., more robust propagation of analytical uncertainties and inter-laboratory age reproducibility studies), there currently are no commonly established protocols for target spot location on polyphase detrital zircon grains: should the analyst ablate the zircon core, rim, or both? Here, we present two regional U-Pb detrital zircon datasets, one from the Banda Arc in Eastern Indonesia and one from the European Alps pro-foreland basin. We demonstrate that preferential ablation solely of cores or rim overgrowths results in a failure to detect age peaks, and also that generation of single-grain core-rim age pairs can permit additional characterisation of the source rock. Thus, both cores and rims should be analysed where possible, to maximise the data obtained from detrital zircon. In addition, we advocate the use of the single-analysis concordia age in visualizing and presenting U-Pb data, which is currently under-utilised in detrital provenance studies. We utilise a large (ca. 49,500 analyses) detrital zircon dataset to demonstrate that the single-analysis concordia age maximises precision throughout geological time (which removes the need to present ages derived from different isotopic ratios across an arbitrary age threshold), and obviates the necessity to separately assess discordance.
\end{abstract}

C 2017 Elsevier B.V. All rights reserved.

\section{Introduction}

Recent developments in U-Pb zircon geochronology by means of laser ablation-inductively coupled plasma mass spectrometry (LA-ICPMS) have allowed for the progressively more rapid and cost-effective acquisition of large datasets, with a significant increase in the amount of new publications every year (e.g., see Fig. 1 of Spencer et al., 2016). However, the ease by which large detrital zircon datasets can be acquired by the geoscience community has led to diverse data handling approaches and interpretations of geochronological data (see discussion by Spencer et al., 2016). Similarly, Gehrels (2014) highlighted how particular approaches to grain selection, isotopic analysis, and subsequent data reduction and filtering can result in interpretation biases. In this contribution,

\footnotetext{
Special Issue: "Analyses of sediment properties: Tools for paleo-environmental reconstructions".

* Corresponding author at: iCRAG @ School of Earth Sciences, University College Dublin, Dublin 4, Ireland.

E-mail address: Sebastian.zimmermann@ucd.ie (S. Zimmermann).
}

we aim to improve on the lack of universally agreed protocols in the LA-ICPMS U-Pb zircon community for: (1) spot positioning on polyphase zircon in detrital provenance studies and (2) subsequent age calculation and discordance filtering.

The highly refractory nature of zircon, even when exposed to hightemperature geological processes such as anatexis or incorporation within magmatic bodies, means that rim overgrowths are common features of zircon grains (e.g., Nemchin and Pidgeon, 1997; Whitehouse and Platt, 2003). As thermally-activated $\mathrm{Pb}$ diffusion in non-metamict zircon occurs only at temperatures $>\mathrm{ca} .900{ }^{\circ} \mathrm{C}$ and is thus negligible in most cases (Cherniak and Watson, 2000), this means that the corerim textures observed in a single zircon grain can record multiple geological events that are routinely resolvable by in situ micro-beam U-Pb geochronometry. Such polyphase single-grain archives are frequently exploited by high-resolution crystalline basement studies targeting small numbers of grains (e.g., Chew et al., 2017a, b); in contrast, detrital provenance studies often texturally characterize zircon grains only to avoid simultaneously ablating multiple age zones during analysis, which would otherwise generate geologically meaningless mixed ages. 
Textural characterisation of zircon is typically conducted using the well-established technique of cathodoluminescence $(\mathrm{CL})$ imaging, often coupled to a scanning electron microscope (SEM; e.g., Vavra, 1990; Vavra et al., 1996; Cavosie et al., 2004). In the case of magmatic zircons (e.g., Nemchin and Pidgeon, 1997), rim overgrowths are typically autocrysts linked to late-stage growth corresponding to crystallization from the final pulses of magma. The zircon cores may represent either antecrysts crystallized from an earlier pulse of melt in the magma plumbing system, or xenocrysts incorporated from the wall-rocks during magma generation and migration. However, it should be noted that in many magmas zircon inheritance does not just comprise inherited zircon cores but also entire inherited zircon grains, and hence zircon rims can also potentially pre-date incorporation into a given magmatic system. Zircon from high-grade metamorphic rocks often exhibits core-rim structures, with metamorphic zircon rims typically characterized by a structureless or patchily-zoned appearance in CL images overgrowing an inherited core (e.g., Gebauer et al., 1997; Whitehouse and Platt, 2003).

Thus, in detrital studies, U-Pb zircon rim data records the last zircon-forming tectonothermal event (either magmatic or hightemperature metamorphic) in the original source rock, while core age data can record inheritance from the local country rocks or co-genetic magmatic ages derived from earlier melt pulses in the magma plumbing system.

However, despite abundant evidence that complex polyphase zircons with clear core-rim age differences are formed in a variety of geological settings (e.g., Carter and Moss, 1999; Whitehouse and Platt, 2003; Wu and Zheng, 2004; Wan et al., 2006; Zhang et al., 2007) and are thus commonly observed in the sedimentary record, there is no consensus on how such grains should be treated during $\mathrm{U}-\mathrm{Pb}$ detrital provenance analysis. During the discussion sessions at the 3rd meeting of the Working Group on Sediment Generation on which this special volume is based, there was also no consensus between different geochronology laboratories on target spot location for detrital zircon grains.

Within the literature examples can be found with the ablation spot preferentially sited on the zircon core (e.g., Goldstein et al., 1997; DeGraaff-Surpless et al., 2002; Amidon et al., 2005; Zimmermann et al., 2015); both the zircon rim and core (e.g., Cawood and Nemchin, 2000; Gehrels, 2014; Spencer et al., 2016), or alternatively the zones with the most homogeneous CL response (e.g., Cao et al., 2015;
Zimmermann and Hall, 2016). In provenance studies from a specific, well-characterized source region where the polyphase growth history of detrital zircon detritus is known, such preferential siting of ablation spots may be justified (i.e. analysts may target cores to trace the contribution of old inherited zircon from different basement massifs, or rims to provide maximum age constraints on deposition). However, given that zircon core and rim age data can yield significantly different provenance information, we propose that both rims and cores should be targeted during routine provenance studies, subject to the physical sampling limits of the analytical procedure employed (micron-thick rim overgrowths are not datable by conventional LA-ICPMS spot analysis on polished grain mounts, for example). To illustrate this, Fig. 1 shows a hypothetical tectonothermal history, and the idealized detrital zircon spectra that would result (Fig. 1A-C). Selective targeting of either rims or cores leads to a less informative dataset than if both are targeted: either tectonothermal events are not identified (Fig. 1B), or are identified but not characterized (Fig. 1C).

We also argue for the routine calculation of single-analysis concordia ages, which utilises information from three isotopic systems $\left({ }^{206} \mathrm{~Pb}_{-}{ }^{238} \mathrm{U},{ }^{207} \mathrm{~Pb}-{ }^{235} \mathrm{U}\right.$, and $\left.{ }^{207} \mathrm{~Pb}-{ }^{206} \mathrm{~Pb}\right)$ to minimize uncertainty, permit simultaneous assessment of discordance, and also remove the necessity of presenting ages derived from different isotopic ratios (e.g., ${ }^{206} \mathrm{~Pb}^{238} \mathrm{U}$ and ${ }^{207} \mathrm{~Pb}-{ }^{206} \mathrm{~Pb}$; Ludwig, 1998). Thus, in this contribution we initially document the utility of the concordia age (Ludwig, 1998) for U-Pb age determinations of single-grain detritus. We use a large, previously published zircon U-Pb dataset (Voice et al., 2011) to demonstrate that single-grain concordia ages yield uncertainties which are both significantly lower in absolute terms than ages derived from a single isotope ratio and are also more uniform over time, as stated by Ludwig (1998). In contrast, ages calculated from single isotope ratios typically show either decreasing $\left({ }^{207} \mathrm{~Pb}-{ }^{206} \mathrm{~Pb}\right)$ or increasing $\left({ }^{206} \mathrm{~Pb}-{ }^{238} \mathrm{U}\right)$ age uncertainties with increasing age, which in turn requires an analyst to decide which of these two age systems is the most geologically appropriate when presenting U-Pb detrital zircon age data (e.g., see discussion in Spencer et al., 2016).

Secondly, we investigate how LA-ICPMS spot positioning can affect provenance interpretations in $\mathrm{U}-\mathrm{Pb}$ detrital zircon studies. We present two regional detrital zircon datasets: one from the outer Banda Arc of eastern Indonesia (Fig. 2A) and a second from the pro-foreland basin of the European Alps (Fig. 2B). Both regions are tectonically complex,

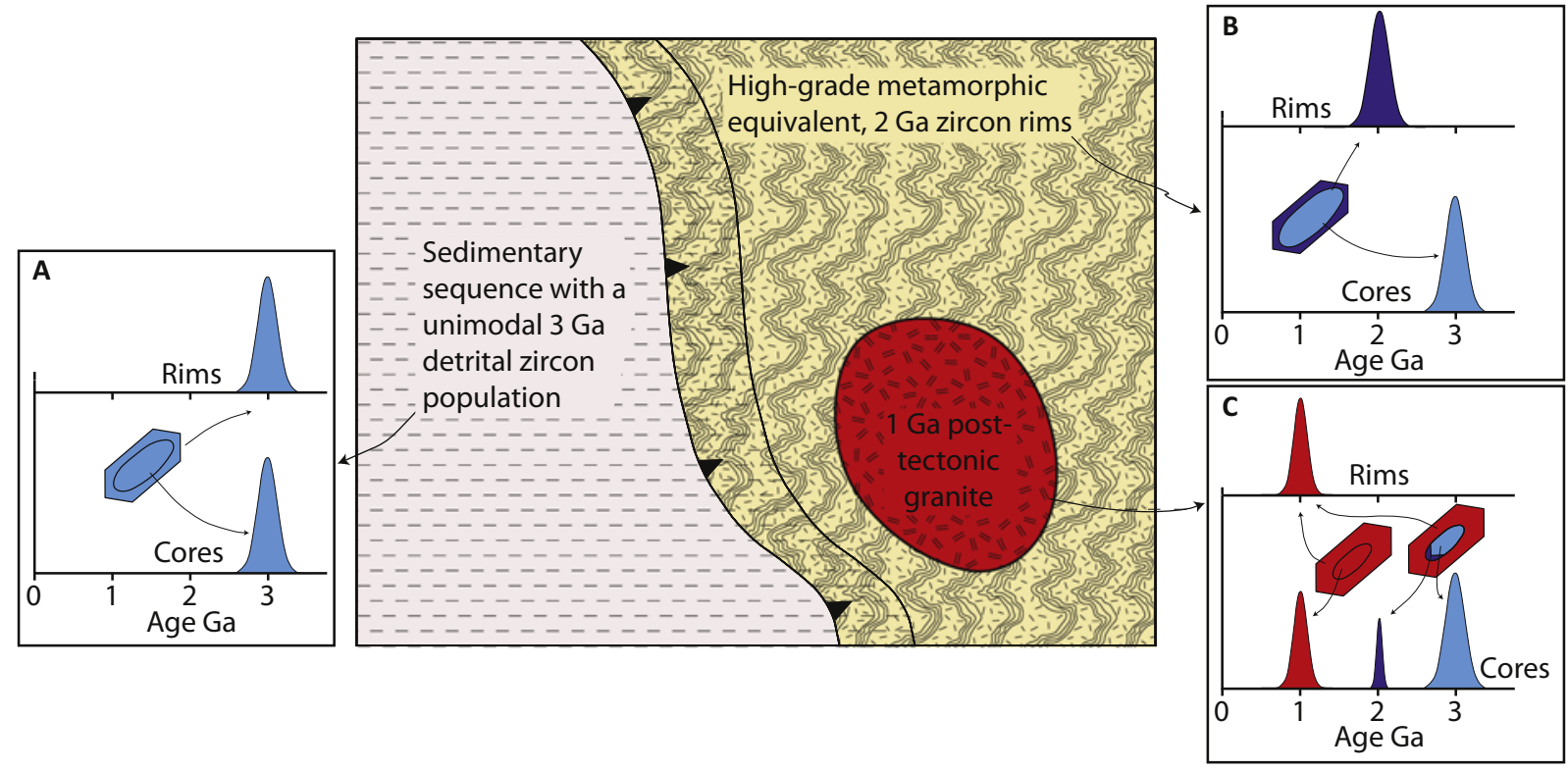

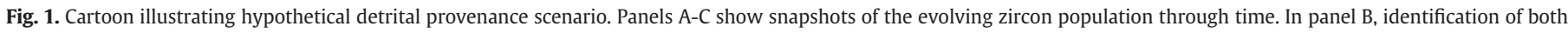

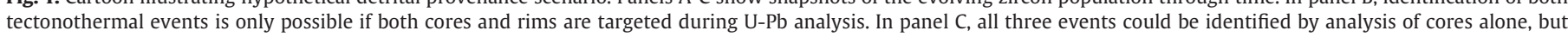
characterisation of the youngest peak as likely recording an igneous event (i.e. indistinguishable core and rim ages) is only possible if both cores and rims are targeted. 

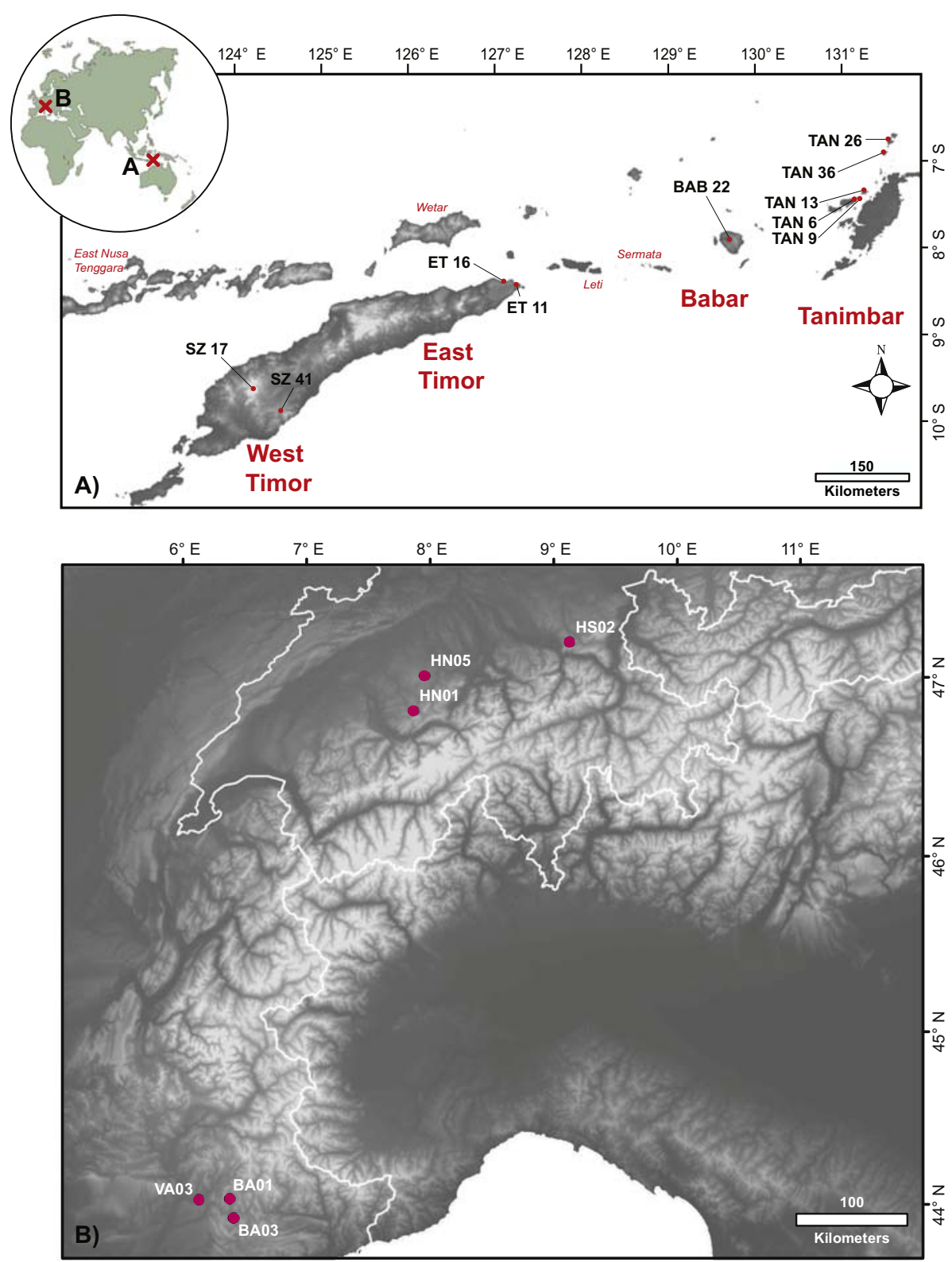

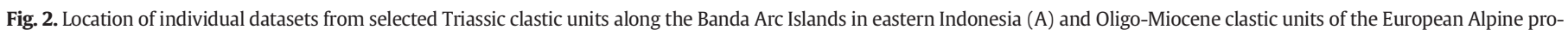
foreland (B).

comprising terranes originally accreted to the margins of major continents (Eurasia and Gondwana, respectively) during the late Neoproterozoic and Phanerozoic. Both areas have been studied in detail, and a summary of their complex geological history is beyond the scope of this study. The reader is directed to Matte (2001) and Stampfli et al. (2013) (Alps), and Charlton (2001), Barber et al. (2003) and Zimmermann and Hall (2016) (Banda Arc) for detailed reviews. Each dataset is of a size typical for regional detrital zircon U-Pb studies (six and eleven samples respectively, each comprising ca. 100 analyses), and includes multiple pairs of core-rim ages. The two datasets were acquired using similar LA-ICPMS protocols and yield a range of ages indicative of a mixed provenance. As only a subset of grains from each study yielded rim overgrowths amenable to conventional LA-ICPMS spot dating and thus to generation of core-rim pairs, the samples from each study were each amalgamated into two large datasets, one for each study area. Both datasets thus comprise several samples of different stratigraphic age and geographical location within each deposystem. We investigate whether employing U-Pb zircon core vs rim ages systematically shifts individual age populations and hence affects subsequent provenance interpretations, and evaluate the additional provenance information obtainable by analysing core-rim pairs on single grains.

\section{Background}

The U-Pb zircon geochronometer exploits the ability of $\mathrm{U}^{4+}$ to substitute for $\mathrm{Zr}^{4+}$ in the zircon mineral lattice $\left(\mathrm{ZrSiO}_{4}\right)$. As the $\mathrm{U}-\mathrm{Pb}$ isotopic system involves two separate decay schemes $\left({ }^{235} \mathrm{U}\right.$ decaying to ${ }^{207} \mathrm{~Pb}$ with a half-life of $0.704 \mathrm{Ga}$ and ${ }^{238} \mathrm{U}$ decaying to ${ }^{206} \mathrm{~Pb}$ with a half-life of $4.468 \mathrm{Ga}$ ), three separate isotopic ages can be calculated for a single analysis: ${ }^{206} \mathrm{~Pb}-{ }^{238} \mathrm{U},{ }^{207} \mathrm{~Pb}-{ }^{235} \mathrm{U}$ and ${ }^{207} \mathrm{~Pb}-{ }^{206} \mathrm{~Pb}$. This allows for the internal age consistency of each analysis to be assessed, and agreement of the ages (within error) is termed concordance (Wetherill, 1956). Due to the significantly shorter half-life and hence substantially lower present-day isotopic abundance of ${ }^{235} \mathrm{U}$, young samples yield low radiogenic ${ }^{207} \mathrm{~Pb}$ count rates during analysis, and hence ${ }^{206} \mathrm{~Pb}-{ }^{238} \mathrm{U}$ ratios are more precise than ${ }^{207} \mathrm{~Pb}-{ }^{235} \mathrm{U}$ and ${ }^{207} \mathrm{~Pb}-{ }^{206} \mathrm{~Pb}$ 
ratios for young samples (e.g., Košler and Sylvester, 2003; Nemchin and Cawood, 2005).

Solution of the two U-Pb age equations for time permits construction of an age evolution line, termed a concordia (as distinct from a concordia age). The two most commonly used concordia plots utilise ${ }^{207} \mathrm{~Pb}-{ }^{235} \mathrm{U}$ and ${ }^{206} \mathrm{~Pb}-{ }^{238} \mathrm{U}$, or ${ }^{238} \mathrm{U}-{ }^{206} \mathrm{~Pb}$ and ${ }^{207} \mathrm{~Pb}-{ }^{206} \mathrm{~Pb}$ as their respective axes (Wetherill, 1956; Tera and Wasserburg, 1972). Analyses which have experienced isotopic disturbance plot off the concordia line. Such so-called discordant analyses are typically interpreted either as recording intra-grain $\mathrm{Pb}$ mobility or $\mathrm{Pb}$ exchange with the external environment (Mezger and Krogstad, 1997; Cherniak and Watson, 2000), or may represent a mixture of two discrete age components. Because such processes may be caused by geological events, discordant ages can still record geochronologically useful information (e.g., Gehrels et al., 2006; Gehrels, 2014; Schoene, 2014; Reimink et al., 2016). However, in cases where discordant analyses do not form clear age arrays (discordia) with resolvable intercepts to the concordia line, there is no way to verify which (if any) of the discordant isotope ratios is geologically meaningful without additional independent information from the same source rock, such as ages derived from independent radioisotope systems. Thus, discordant ages are typically excluded from detrital datasets (e.g., Gehrels, 2012).

However, what criteria should be used to assess discordance and justify exclusion? The level of acceptable discordance is seldom discussed and the choice of discordance filter $\left({ }^{207} \mathrm{~Pb}^{235} \mathrm{U}\right.$ vs ${ }^{206} \mathrm{~Pb}^{238} \mathrm{U}$ age or ${ }^{206} \mathrm{~Pb}^{238} \mathrm{U}$ vs ${ }^{207} \mathrm{~Pb}-{ }^{206} \mathrm{~Pb}$ age ) in a study is rarely justified (Spencer et al., 2016), yet discordance assessment and age rejection can significantly influence data interpretations (Nemchin and Cawood, 2005). Typically, discordance filters are set between 5 and $10 \%$ above and below the concordia, but discordance filters as large as $30 \%$ have also been used in the literature (cf Reimink et al., 2016).

\subsection{The single analysis concordia age calculation}

In this study, we utilise concordia ages (Ludwig, 1998) to present our detrital zircon data. Concordia ages are rarely used in detrital provenance studies, (although see McAteer et al., 2010 for one such example), but are advantageous because: (1) they make optimum use of both U-Pb decay schemes, resulting in smaller age uncertainties extending back through geological time compared to ages calculated from the single isotope ratios ${ }^{207} \mathrm{~Pb}-{ }^{235} \mathrm{U},{ }^{206} \mathrm{~Pb}^{238} \mathrm{U}$ or ${ }^{207} \mathrm{~Pb}-{ }^{206} \mathrm{~Pb}$ (Ludwig, 1998); (2) this improved precision in turn removes the need to choose a "preferred" single isotope ratio for an age determination (or an age threshold to switch from ${ }^{206} \mathrm{~Pb}-{ }^{238} \mathrm{U}$ ages to ${ }^{207} \mathrm{~Pb}-{ }^{206} \mathrm{~Pb}$ ages) as they are invariably more precise than an age derived from a single isotopic system; and (3) they eliminate the need for a separate discordance calculation, as the probability and MSWD of concordance can be calculated simultaneously. The Isoplot add-in for Microsoft Excel (Ludwig, 2008) can calculate either conventional (Wetherill) or Tera-Wasserburg concordia ages for single or multiple analyses. For multiple analyses of a single age population (e.g., a magmatic rock), the Isoplot concordia age dialog box only returns a concordia age if both the probability of data-point equivalence and the probability of concordance are $>0.001$. For single analyses (relevant to U-Pb detrital provenance studies), it should be noted the concordia age function always returns an age, which must then be assessed for concordance. This is simply achieved using a threshold value of 0.001 for the probability of concordance value returned by the Isoplot function, and is the same threshold value employed in concordia age calculations of multiple analyses in Isoplot (Ludwig, 2008).

To examine how the uncertainty of the concordia age calculation compares to that of ${ }^{206} \mathrm{~Pb}^{238} \mathrm{U},{ }^{207} \mathrm{~Pb}-{ }^{235} \mathrm{U}$ and ${ }^{207} \mathrm{~Pb}-{ }^{206} \mathrm{~Pb}$ ages through geological time, we utilised the large global detrital zircon U-Pb dataset of Voice et al. (2011) comprising $>200,000$ analyses, along with more recent $\mathrm{U}-\mathrm{Pb}$ zircon studies added to their dataset. Data were initially screened for analyses made using LA-ICPMS instruments and for which ${ }^{206} \mathrm{~Pb}-{ }^{238} \mathrm{U},{ }^{207} \mathrm{~Pb}-{ }^{235} \mathrm{U}$ and ${ }^{207} \mathrm{~Pb}-{ }^{206} \mathrm{~Pb}$ isotope ratios were reported, and concordia ages were calculated. The dataset was then filtered for a probability of concordance $>0.001$, resulting in ca. 49,500 LA-ICPMS acceptable single-analysis zircon concordia ages. Best-fit trendlines were then fitted to each of the two-dimensional density estimation diagrams of age uncertainty vs age (Fig. 3A-D).

While these trends, summarised on Fig. 3E, are somewhat influenced by both the choice and goodness-of-fit of the trendline, it is immediately apparent that the ${ }^{207} \mathrm{~Pb}-{ }^{206} \mathrm{~Pb}$ age is more precise than the ${ }^{206} \mathrm{~Pb}^{238} \mathrm{U}$ age for U-Pb ICPMS zircon analyses older than ca. $1.5 \mathrm{Ga}$ (an identical finding to the similar analysis of Spencer et al., 2016 on the same dataset). However, we also show that the ${ }^{207} \mathrm{~Pb}-{ }^{235} \mathrm{U}$ age is typically more precise than the ${ }^{207} \mathrm{~Pb} /{ }^{206} \mathrm{~Pb}$ age for analyses younger than ca. $1.9 \mathrm{Ga}$, and is additionally more precise than the ${ }^{206} \mathrm{~Pb}^{238} \mathrm{U}$ age for analyses older than ca. $1 \mathrm{Ga}$ (Fig. 3E). This is because although the abundance of radiogenic ${ }^{206} \mathrm{~Pb}$ is always greater than the abundance of radiogenic ${ }^{207} \mathrm{~Pb}$ in terrestrial zircon, the vast majority of detrital zircon data (including that in the Voice et al., 2011 dataset) are produced using single-collector (either quadrupole or sector field) LA-ICPMS systems. These systems cannot simultaneously analyse ${ }^{207} \mathrm{~Pb},{ }^{206} \mathrm{~Pb}$ or ${ }^{238} \mathrm{U}$, and so individual dwell times are set for each isotope. As most analysts use longer dwell times (up to 3 or 4 times longer, Spencer et al., 2016) for the low abundance ${ }^{207} \mathrm{~Pb}$ isotope, the resultant ${ }^{207} \mathrm{~Pb} /{ }^{235} \mathrm{U}$ uncertainty can be less than that for ${ }^{206} \mathrm{~Pb} /{ }^{238} \mathrm{U}$ in old, radiogenic zircons (e.g., Fig. 3E). This clearly would not be the case for zircon data acquired using instruments equipped for simultaneous isotope detection (e.g., LA-ICPMS multi-collector systems).

Most importantly, our analysis shows that the concordia age is the most precise $\mathrm{U}-\mathrm{Pb}$ age calculation through geological time, which thus removes the need to choose a "preferred" single isotope ratio (e.g., ${ }^{206} \mathrm{~Pb}-{ }^{238} \mathrm{U}$ vs ${ }^{207} \mathrm{~Pb}-{ }^{206} \mathrm{~Pb}$ ) for an age determination. The apparent slight improvement in the precision of ${ }^{206} \mathrm{~Pb}^{238} \mathrm{U}$ ages compared to the concordia age calculation for very young samples (Fig. 3E) is a minor artefact caused by the trendline fit at very young ages. The uncertainties on the ${ }^{206} \mathrm{~Pb}-{ }^{238} \mathrm{U}$ and concordia age are essentially identical for ages younger than Late Palaeozoic (Ludwig, 1998, 2008), as the concordia age uncertainty is heavily influenced by the superior precision on the ${ }^{206} \mathrm{~Pb}-{ }^{238} \mathrm{U}$ ratio for young samples.

\subsection{Core-rim ages from new zircon $\mathrm{U}-\mathrm{Pb}$ data}

\subsubsection{SE Asia samples}

The samples presented derive from selected Triassic clastic units along the outer Banda Arc Islands (Zimmermann and Hall, 2016), which are part of a larger dataset reported by Zimmermann and Hall (2016). The 63-250 $\mu \mathrm{m}$ non-magnetic heavy mineral fraction was extracted using standard crushing, sieving, magnetic- and density separation techniques. Individual zircon grains were hand-picked, mounted in epoxy resin and polished to reveal internal surfaces. Selected samples were imaged by SEM CL (Jeol8100 Superprobe) at University College London, and texturally homogenous cores and rims targeted for ablation. U-Pb analyses were acquired at University College London using an Agilent Technologies 7700 Series quadrupole ICPMS, coupled to a New Wave NWR $193 \mathrm{~nm}$ laser ablation system (1-volume cell); He gas was utilised for transfer of the aerosol to the plasma. Parameters used were a spot size of 20-35 $\mu \mathrm{m}$; pulse repetition of 8-10 Hz; ablation time of $25 \mathrm{~s}$ with a warm-up of $10-15 \mathrm{~s}$ (background measurement at the start of each analysis) and wash-out of $18 \mathrm{~s}$. The Plešovice zircon (Sláma et al., 2008) and reference glass NIST SRM 612 (Pearce et al., 1997) standards were used to correct for instrumental mass bias, intra-session drift, and depth-dependent inter-element fractionation of $\mathrm{Pb}$, Th and $\mathrm{U}$. Data reduction was performed using the Glitter software package (Griffin et al., 2008). Concordia ages were calculated with the Isoplot add-in for Microsoft Excel (Ludwig, 2008) and kernel density plots were generated with DensityPlotter (Vermeesch, 2012). See Supplementary Information A1 for the sample 

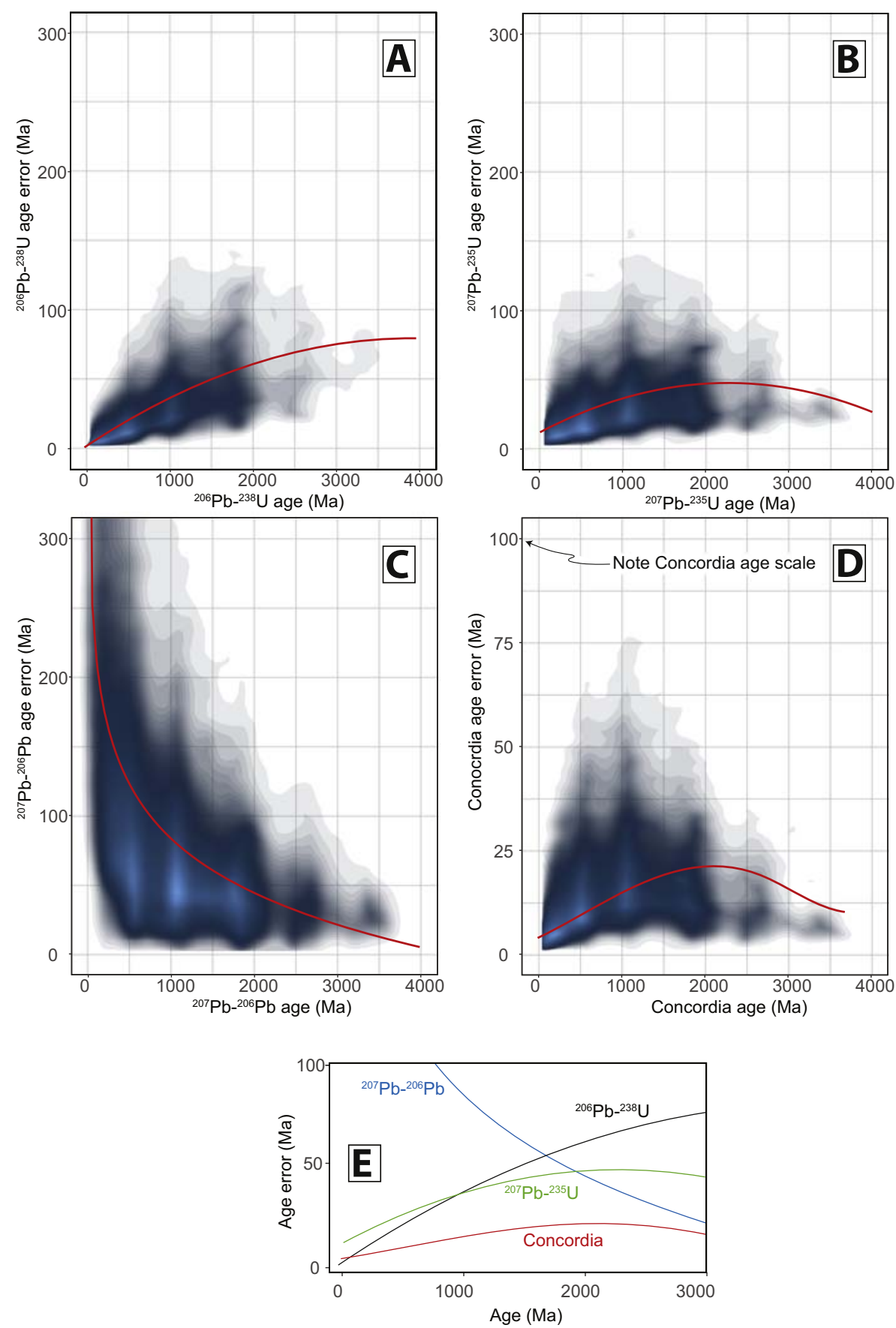

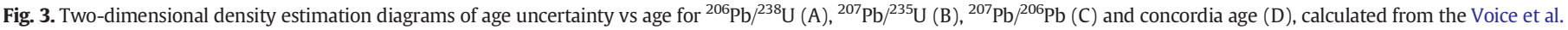

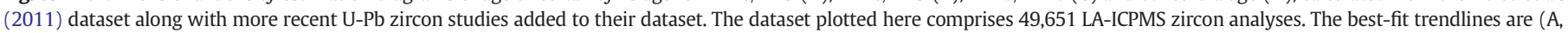

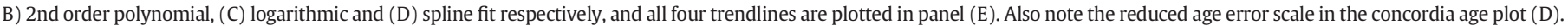

locations, deposition ages, and fully tabulated reduced isotope data and $\mathrm{U}-\mathrm{Pb}$ ages.

\subsubsection{European Alps samples}

Samples were collected from Oligo-Miocene clastic units of the Alpine pro-foreland basin (Ford and Lickorish, 2004). The sub-300 $\mu \mathrm{m}$ non-magnetic heavy mineral fraction was extracted from rock samples via standard crushing, sieving, and magnetic and density separation techniques. Zircon grains were hand-picked using a Nikon SMZ 1500 binocular microscope. To avoid sample bias, no attempt was made to exclude anhedral grains. Samples were mounted in epoxy resin, ground to reveal internal surfaces, and polished. Grain textures were characterized using a CL imaging system mounted to a Tescan MIRA SEM. All U-Pb analyses were made using a Thermo Scientific iCAP Qc quadrupole mass spectrometer, coupled to a Photon Machines Analyte Excite $193 \mathrm{~nm}$ ArF excimer laser at Trinity College Dublin. Spot sizes of 30 and $36 \mu \mathrm{m}$ diameter were used with a fluence of $3.9 \mathrm{~J} \mathrm{~cm}^{-2}$, a pulse rate of $5 \mathrm{~Hz}$, and total analysis time of $70 \mathrm{~s}$, comprising $45 \mathrm{~s}$ of ablation followed by a $25 \mathrm{~s}$ background measurement. Downhole fractionation and intrasession analytical drift were corrected for using either the 91,500 or Plešovice as the primary and the Temora zircon as the secondary zircon mineral standard, together with NIST glass SRM 612 (Wiedenbeck et al., 1995; Pearce et al., 1997; Black et al., 2003; Sláma et al., 2008). Data reduction was carried out using the VizualAge data reduction scheme for the IOLITE extension to the Igor Pro analytical software package (Paton et al., 2011; Petrus and Kamber, 2012). Calculation of concordia 
ages and generation of concordia plots was performed using the Isoplot add-in for Microsoft Excel (Ludwig, 2008), and kernel density plots and peak ages were generated using DensityPlotter (Vermeesch, 2012). Data for a subset of these samples was previously reported by Mark et al. (2016). See Supplementary Information A2 for sample locations, depositional ages, and fully tabulated reduced isotope data and $\mathrm{U}-\mathrm{Pb}$ ages.

\section{Results}

For the Banda Arc, we present data from 1560 zircon analyses derived from eleven samples with Triassic depositional ages. A total of 995 acceptable (probability of concordance $>0.001$ ) zircon U-Pb concordia ages (Fig. 4A) were obtained (pass rate of 64\%); while 1297 grains pass at a $10 \%$ conventional discordance filter and 1074 grains pass using a $5 \%$ conventional discordance filter (pass rate of $69 \%$, similar to the concordia age pass rate). Hence this dataset is characterized by appreciable discordance, but would not be atypical of many detrital datasets. The dataset comprises 51 rim overgrowth ages (Fig. 4B) with 36 core-rim age pairs presented here (Fig. 5A), as 15 rim ages derive from zoned zircons yielding discordant core ages and were excluded.

From the Alps, we present a total of 579 acceptable (probability of concordance $>0.001$ ) zircon $\mathrm{U}-\mathrm{Pb}$ concordia ages on 482 separate grains from six samples deposited during the Oligo-Miocene, including $97 \mathrm{rim}$ overgrowth ages (Fig. 4C). Grains yielding core-rim age pairs which were indistinguishable at the $2 \sigma$ level were interpreted as recording magmatic zoning, leaving 41 core-rim age pairs (Fig. 4D) interpreted as recording metamorphic or magmatic overgrowths on antecrystic or xenocrystic cores (Fig. 5B).

A)

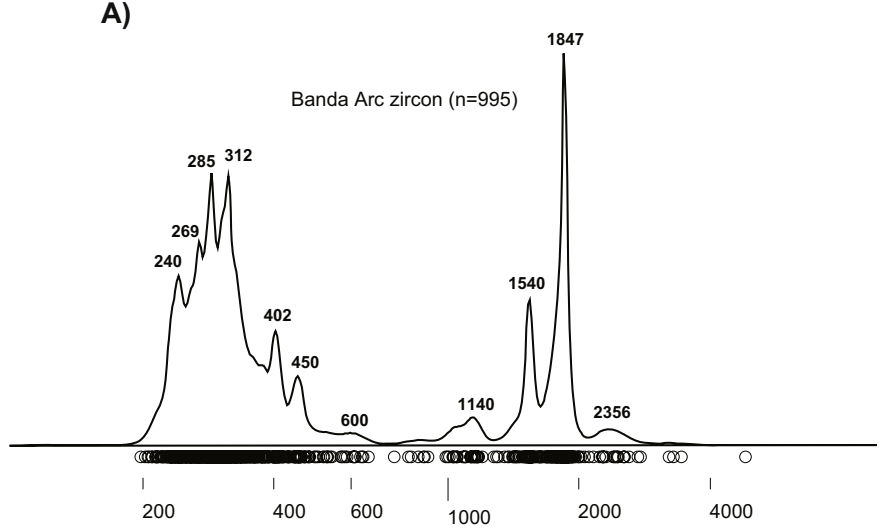

B)

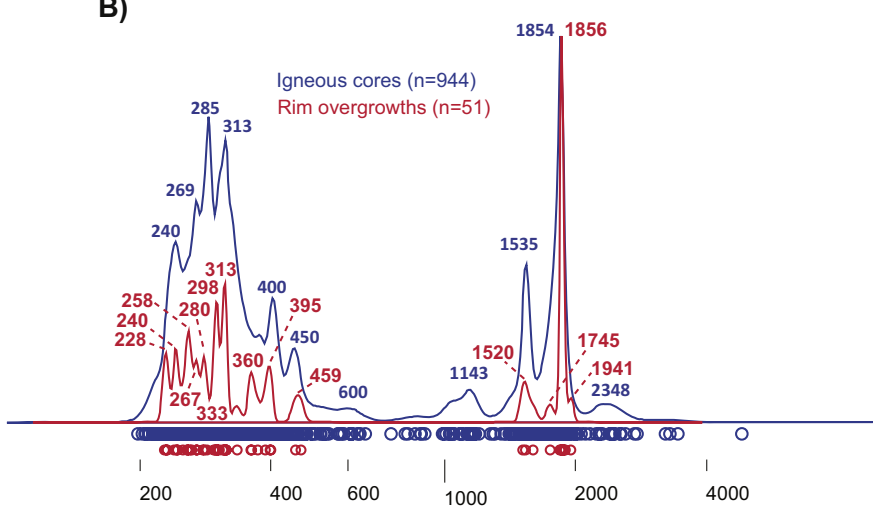

\section{Discussion}

\subsection{Core vs rim analyses and core-rim age pairs}

The Banda Arc dataset (Fig. 4A) records peaks at ca. 1847 Ma, indicating Northern/Central Australian provenance; 1540 Ma and 1140 Ma populations associated with Western Australian origin (Southgate et al., 2011; Lewis and Sircombe, 2013); and a series of peaks between 600 and $402 \mathrm{Ma}$ and a major, composite PermoTriassic peak between 312 and 240 Ma which records prolonged magmatic activity in the Bird's Head region of New Guinea (Gunawan et al., 2012; Zimmermann and Hall, 2016). Age peaks generated only from rim overgrowths generally do not show major differences to the complete dataset ( $<3 \%$ in almost all cases; Fig. $4 \mathrm{~B})$. However, there are four exceptions. Neither the Paleoproterozoic (ca. $2348 \mathrm{Ma}$ ), nor the Mesoproterozoic peak at ca. $1145 \mathrm{Ma}$, nor the late Neoproterozoic peak (ca. $600 \mathrm{Ma}$ ) observed in the complete dataset are recorded by the rim overgrowth dataset. The otherwise close agreement between age peaks of the complete dataset and rim overgrowth dataset suggests that these differences are not sampling artefacts arising from differences in sample size. Between acceptable core-rim age pairs (Fig. 5A), it is noticeable that in most cases the core and rim ages are indistinguishable at the $2 \sigma$ level. A distinctive difference can be seen in grain T13-14/15 which yields an Archean core with a Paleoproterozoic overgrowth rim. In summary, ablation of grain rims only would have excluded detection of Meso- and Neoproterozoic events.

In the Alpine pro-foreland samples (Fig. 4C), the complete dataset records a minor Grenville-age peak at ca. $1012 \mathrm{Ma}$; a series of peaks between ca. $688 \mathrm{Ma}$ and $535 \mathrm{Ma}$ which likely record Cadomian arc magmatism and collision with Gondwana; a prominent Caledonian-age (Eo-Variscan) peak at ca. $449 \mathrm{Ma}$; Variscan-age peaks at ca. $328 \mathrm{Ma}$ and

C)

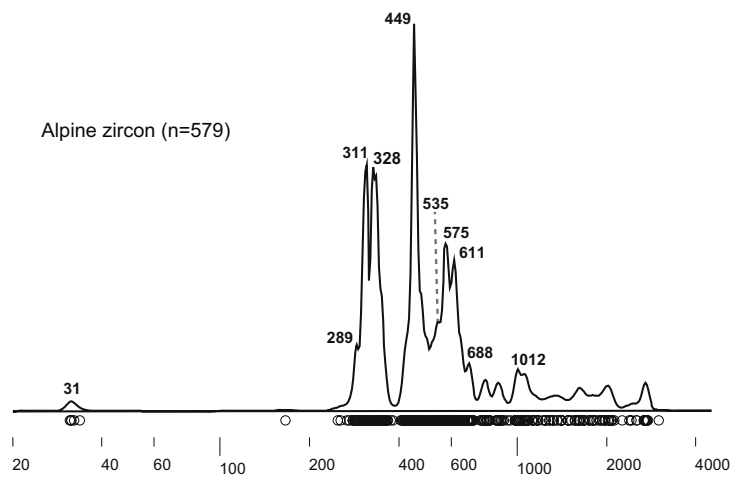

D)

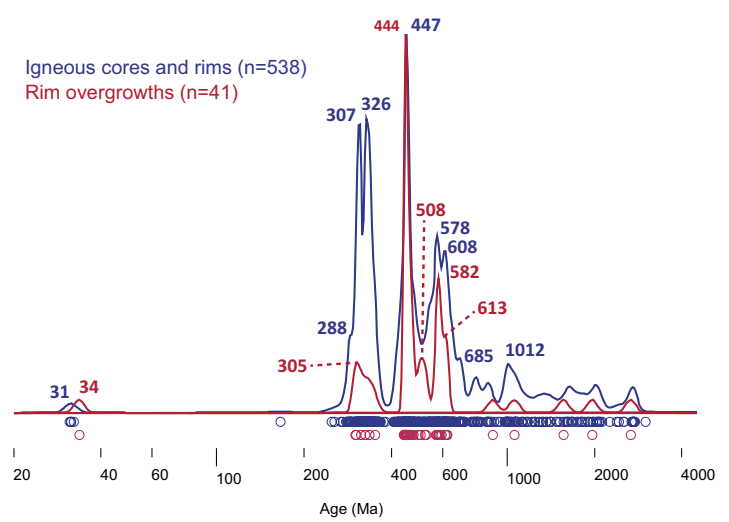

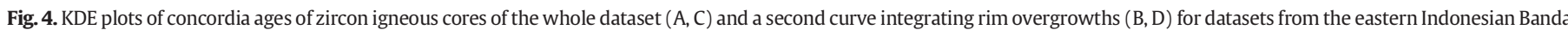
Arc and the European Alps pro-foreland. 

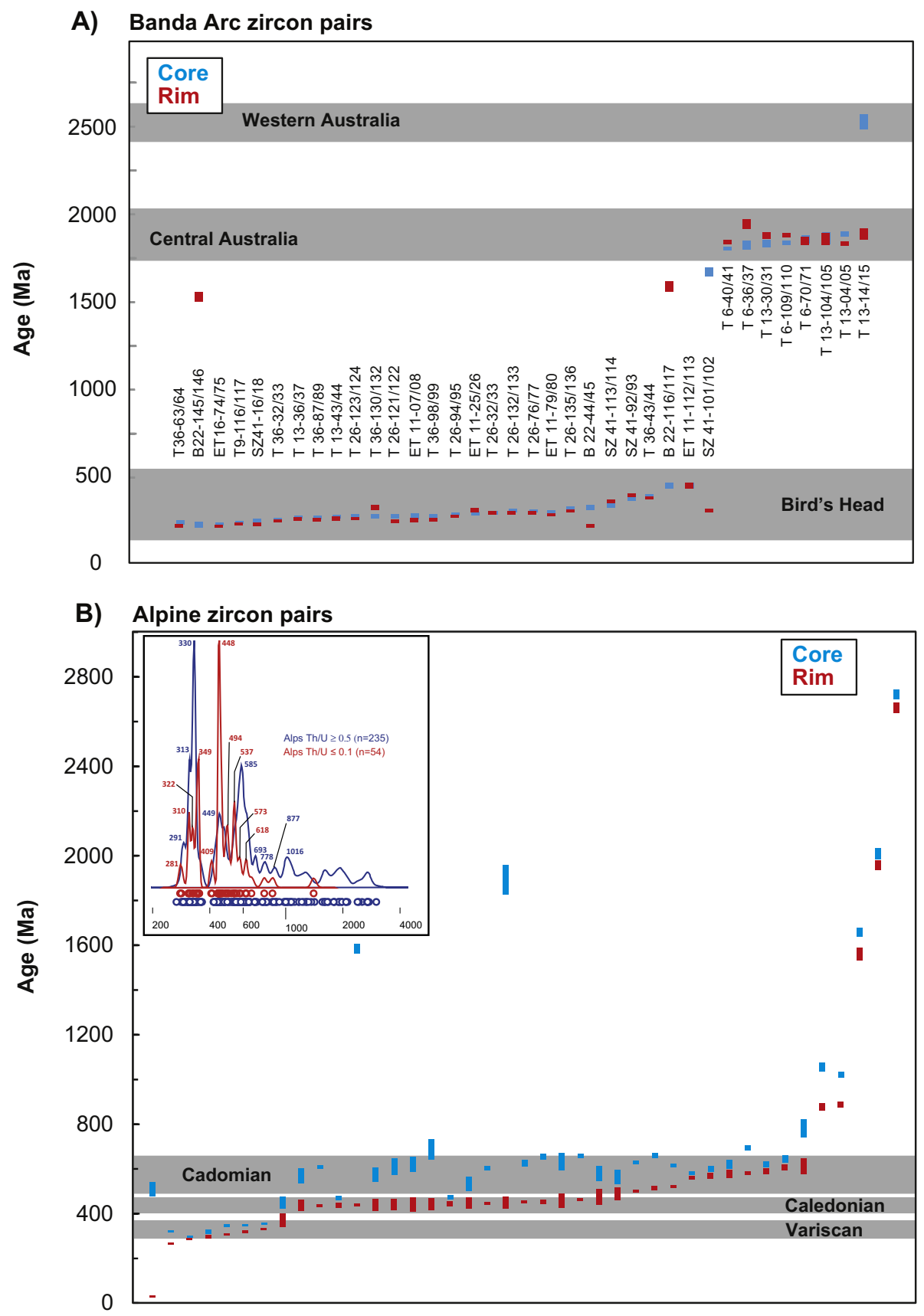

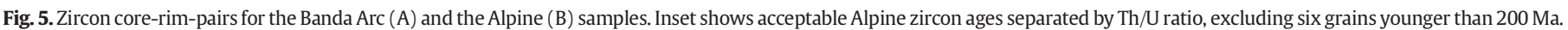
Grains with $\mathrm{Th} / \mathrm{U} \geq 0.5$ are likely igneous; grains with $\mathrm{Th} / \mathrm{U} \leq 0.1$ are likely metamorphic.

$311 \mathrm{Ma}$; and a minor peak at ca. 289 Ma which likely records endVariscan magmatism (Matte, 2001; Linnemann et al., 2007; Stampfli et al., 2013; Rivers, 2015; and references therein). Despite all samples being collected from the pro-foreland basin of the Alpine orogen, only a very minor Alpine-age peak at ca. $31 \mathrm{Ma}$ is observed, comprised of just four analyses. These likely record Periadriatic volcanism, widespread in the central Alps but also reported from the western Alps (Waibel, 1993; Jourdan et al., 2013; Mark et al., 2016). Separation of rim overgrowths from the remainder of the dataset (Fig. 4D) does not result in significant changes to most peak ages observed in the complete dataset ( $\leq 1 \%$ in all cases), although the Grenville-age peak is not recorded by the rim overgrowths. In addition, one new peak is detected at ca. $508 \mathrm{Ma}$ by the rim overgrowths. Although a minor peak in the rim dataset, it corresponds to a minima in the complete dataset (Fig. 4D). Ablation of grain cores only would have failed to detect this peak, which likely records either the final accretion of the Cadomian arc to Gondwana, generally accepted as of mid-Cambrian age, or post-Cadomian magmatism associated with rifting of the Gondwanan margin (Linnemann et al., 2007; Stampfli et al., 2013). The fact that only the rim overgrowths record the $508 \mathrm{Ma}$ event suggest it may be a metamorphic rim, rather than magmatic.

When only the single-grain core-rim pairs which yield ages distinguishable at $2 \sigma$ are considered (Fig. 5B), the age spread between core and rim appears to vary systematically. In particular, Variscanage rims are in all cases developed on cores which are also Variscan in age, whereas Caledonian-age rims are mostly developed on Cadomian age cores. Cadomian-age rims are mostly developed on Cadomian-age cores. Although the small size of this dataset $(n=41)$ prevents a definitive conclusion, the observed spreads in core-rim ages are in 
good agreement with the $\mathrm{Th} / \mathrm{U}$ ratio of the grains from the complete Alpine dataset (Fig. 5B, inset). The Th/U ratio of zircon is a commonly employed criterion to discriminate between magmatic and metamorphic paragenesis, where $\mathrm{Th} / \mathrm{U}>0.1$ usually indicates a magmatic origin and $\mathrm{Th} / \mathrm{U}<0.1$ usually indicates a metamorphic origin (Lopez-Sanchez et al., 2016 and references therein). However, metamorphic zircon overgrowths can have Th/U values of $>0.1$ (e.g., Schaltegger et al., 1999), while most Th/U values in magmatic zircons are above 0.5 (Hoskin and Schaltegger, 2003). Hence, we employ a $\mathrm{Th} / \mathrm{U}$ ratio $\geq 0.5$ as indicating a magmatic origin and $\mathrm{a} \mathrm{Th} / \mathrm{U}$ ratio $\leq 0.1$ as denoting a metamorphic origin, even though this excludes just over half the grains in our dataset (Fig. 5B inset). The Th/U data (Fig. 5B inset) indicate that the Variscan and Cadomian are dominated by igneous grains, but the Caledonian event is dominantly metamorphic. Of course, these conclusions apply only to the original source rocks contributing to our dataset, and cannot be extrapolated to the entire orogen.

Thus, observed spreads in core-rim ages may provide additional information on the tectonothermal history of the source. For example, higher temperature tectonomagmatic events may be less prone to preserve antecrystic or xenocrystic cores. Alternatively, this may reflect the tectonic environment and the availability of xenocrysts for scavenging, which is likely lower in arc settings than in continental orogens, for example (e.g., Hopkinson et al., 2017). In summary, analysis of zircon cores alone would have failed to detect the ca. $508 \mathrm{Ma}$ event, and analysis of zircon rims alone would have failed to detect the Grenvilleage event.

\section{Conclusions}

Our data demonstrate that selective ablation of only cores or rim overgrowths in texturally polyphase zircon means that some tectonothermal events may be missed. In the case of our Banda Arc dataset, a Paleoproterozoic, a Mesoproterozoic and a late Neoproterozoic age peak recorded by zircon cores were not observed in the rim overgrowth dataset. In the Alps, a minor mid-Cambrian age peak was recorded only by the rim overgrowths. Failure to detect source area age peaks is undesirable in detrital provenance studies; given the relative ease with which large numbers of detrital zircon from conventional samples can now be characterized by CL-SEM and analysed by LA-ICPMS, we urge researchers to consider routinely targeting both cores and rims where practicable. This can now be achieved with ultra-fast spot U-Pb LA-ICPMS analyses using rapid aerosol introduction systems (cf Chew et al., 2017a, b), which can be combined with other multi-proxy U-Pb datasets (e.g., apatite and rutile; O'Sullivan et al., 2016). Generation of comprehensive single-grain core-rim age pair datasets can also help characterize further tectonothermal episodes recorded in the zircon data (e.g., magmatic versus metamorphic events), and can yield additional provenance information if source rocks are well-characterized.

We also urge routine use of single-analysis concordia ages. Comparison of concordia and single isotope ratio ages (i.e., ${ }^{206} \mathrm{~Pb}-{ }^{238} \mathrm{U}$, ${ }^{207} \mathrm{~Pb}-{ }^{235} \mathrm{U}$ and ${ }^{207} \mathrm{~Pb}-{ }^{206} \mathrm{~Pb}$ ) calculated for ca. 49,500 LA-ICPMS zircon $\mathrm{U}-\mathrm{Pb}$ analyses demonstrates that the concordia age provides the greatest precision through geological time, and the precision varies less with age, as identified by Ludwig $(1998,2008)$. In contrast, single isotope ratio ages systematically display less $\left({ }^{206} \mathrm{~Pb}-{ }^{238} \mathrm{U}\right)$ or greater $\left({ }^{207} \mathrm{~Pb}-{ }^{206} \mathrm{~Pb}\right)$ precision with decreasing age.

\section{Acknowledgements}

Collection of the Banda Arc dataset was funded by the SE Asia Research Group at Royal Holloway University of London, supported by a consortium of oil companies including BP, ENI, Inpex, Murphy, Niko, Repsol, Shell and Statoil. Collection of the Alps dataset was funded by Science Foundation Ireland under grant number 12/IP/1663 awarded to DC. This research was supported in part by research grant $13 / \mathrm{RC} /$ 2092 from Science Foundation Ireland and is co-funded under the
European Regional Development Fund and by PIPCO RSG and its member companies. We thank Kerstin Drost for helpful discussion.

\section{Appendix A. Supplementary data}

Supplementary data to this article can be found online at https://doi. org/10.1016/j.sedgeo.2017.12.020.

\section{References}

Amidon, W.H., Burbank, D.W., Gehrels, G.E., 2005. Construction of detrital mineral populations: insights from mixing of $\mathrm{U}-\mathrm{Pb}$ zircon ages in Himalayan rivers. Basin Research 17, 463-485.

Barber, P., Carter, P., Fraser, T., Baillie, P., Myers, K., 2003. Paleozoic and Mesozoic petroleum systems in the Timor and Arfura Seas, Eastern Indonesia. Indonesian Petroleum Association, Proceedings 29th Annual Convention, Jakarta 1, pp. 485-500.

Black, L.P., Kamo, S.L., Allen, C.M., Aleinikoff, J.N., Davis, D.W., Korsch, R.J., Foudoulis, C. 2003. TEMORA 1: a new zircon standard for Phanerozoic U-Pb geochronology. Chemical Geology 200, 155-170.

Cao, L., Jiang, T., Wang, Z., Zhang, Y., Sun, H., 2015. Provenance of Upper Miocene sediments in the Yinggehai and Qiongdongnan basins, northwestern South China Sea: evidence from REE, heavy minerals and zircon U-Pb ages. Marine Geology 361, 136-146.

Carter, A., Moss, S.J., 1999. Combined detrital-zircon fission-track and U-Pb dating: a new approach to understanding hinterland evolution. Geology 27, 235-238.

Cavosie, A.J., Wilde, S.A., Liu, D., Weiblen, P.W., Valley, J.W., 2004. Internal zoning and U-Th-Pb chemistry of Jack Hills detrital zircons: a mineral record of early Archean to Mesoproterozoic (4348-1576 Ma) magmatism. Precambrian Research 135, 251-279.

Cawood, P., Nemchin, A., 2000. Provenance record of a rift basin: $\mathrm{U} / \mathrm{Pb}$ ages of detrital zircons from the Perth Basin, Western Australia. Sedimentary Geology 134, 209-234.

Charlton, T.R., 2001. Permo-Triassic evolution of Gondwanan eastern Indonesia, and the final Mesozoic separation of SE Asia from Australia. Journal of Asian Earth Sciences 19, 595-617.

Cherniak, D., Watson, E., 2000. Pb diffusion in zircon. Chemical Geology 172, 5-24.

Chew, D., Drost, K., Petrus, J.A., 2017a. Fast ( $>50$ Hz) U-Pb LA-ICPMS spot dating of U-bearing minerals using an aerosol rapid introduction system. Program Abstracts of the Goldschmidt 2017 Meeting, Paris.

Chew, D., Petrus, J.A., Kenny, G.G., McEvoy, N., 2017b. Rapid high-resolution U-Pb LA-QICPMS age mapping of zircon. Journal of Analytical Atomic Spectrometry 32, 262-276.

DeGraaff-Surpless, K., Graham, S.A., Wooden, J.L., McWilliams, M.O., 2002. Detrital zircon provenance analysis of the Great Valley Group, California: evolution of an arc-forearc system. Geological Society of America Bulletin 114, 1564-1580.

Ford, M., Lickorish, W.H., 2004. Foreland basin evolution around the western Alpine Arc In: Joseph, P., Lomas, S.A. (Eds.), Deep-Water Sedimentation in the Alpine Basin of SE France: New Perspectives on the Grès d'Annot and Related Systems. Geological Society of London, Special Publications 221:pp. 39-63. https://doi.org/10.1144/GSL SP.2004.221.01.04

Gebauer, D., Schertl, H.-P., Brix, M., Schreyer, W., 1997. 35 Ma old ultrahigh-pressure metamorphism and evidence for very rapid exhumation in the Dora Maira Massif, Western Alps. Lithos 41, 5-24.

Gehrels, G., 2012. Detrital Zircon U-Pb Geochronology: Current Methods and New Opportunities. Tectonics of Sedimentary Basins: Recent Advances. pp. 45-62.

Gehrels, G., 2014. Detrital zircon U-Pb geochronology applied to tectonics. Annual Review of Earth and Planetary Sciences 42, 127-149.

Gehrels, G., Valencia, V., Pullen, A., 2006. Detrital zircon geochronology by laser-ablation multicollector ICPMS at the Arizona LaserChron Center. Paleontological Society Papers $12,67$.

Goldstein, S., Arndt, N., Stallard, R., 1997. The history of a continent from U/Pb ages of zircons from Orinoco River sand and $\mathrm{Sm} / \mathrm{Nd}$ isotopes in Orinoco basin river sediments. Chemical Geology 139, 271-286.

Griffin, W., Powell, W., Pearson, N., O'reilly, S., 2008. GLITTER: Data Reduction Software for Laser Ablation ICP-MS. Laser Ablation-ICP-MS in the Earth Sciences. Mineralogical Association of Canada Short Course Series 40 pp. 204-207.

Gunawan, I., Hall, R., Sevastjanova, I., 2012. Age, character and provenance of the Tipuma Formation, West Papua: new insights from detrital zircon dating. Proceedings Indonesian Petroleum Association 36th Annual Convention, IPA12-G-027, pp. 1-14.

Hopkinson, T.N. Harris, N.B.W., Warren, C.J., Spencer, C.J., Roberts, N.M.W., Horstwood, M.S.A., Parrish, R.R., EIMF, 2017. The identification and significance of pure sediment-derived granites. Earth and Planetary Science Letters 467:57-63. https:// doi.org/10.1016/j.epsl.2017.03.018.

Hoskin, P.W.O., Schaltegger, U., 2003. The composition of zircon and igneous and metamorphic petrogenesis. In: Hanchar, J.M., Hoskin, P.W.O. (Eds.), Zircon, Mineralogical Society of America Reviews in Mineralogy and Geochemistry. 53:pp. 27-62. https://doi.org/10.2113/0530027.

Jourdan, S., Bernet, M., Tricart, P., Hardwick, E., Paquette, J.-L., Guillot, S., Dumont, T. Schwartz, S., 2013. Short-lived, fast erosional exhumation of the internal western Alps during the late early Oligocene: constraints from geothermochronology of proand retro-side foreland basin sediments. Lithosphere 5:211-225. https://doi.org/ 10.1130/L243.1.

Košler, J., Sylvester, P.J., 2003. Present trends and the future of zircon in geochronology: laser ablation ICPMS. Reviews in Mineralogy and Geochemistry 53, 243-275. 
Lewis, C.J., Sircombe, K., 2013. Use of U-Pb geochronology to delineate provenance of NorthWest Shelf sediments, Australia. In: M. K., S.JM. (Eds.), The Sedimentary Basins of Western Australia, Perth, WA.

Linnemann, U., Gerdes, A., Drost, K., Buschmann, B., 2007. The continuum between Cadomian orogenesis and opening of the Rheic Ocean: constraints from LA-ICP-MS $\mathrm{U}-\mathrm{Pb}$ zircon dating and analysis of plate-tectonic setting (Saxo-Thuringian zone, northeastern Bohemian Massif, Germany). Geological Society of America Special Papers 423, 61-96.

Lopez-Sanchez, M.A., Aleinikoff, J.N., Marcos, A., Martínez, F.J., Llana-Fúnez, S., 2016. An example of low-Th/U zircon overgrowths of magmatic origin in a late orogenic Variscan intrusion: the San Ciprián massif (NW Spain). Journal of the Geological Society $173,282-291$.

Ludwig, K.R., 1998. On the treatment of concordant uranium-lead ages. Geochimica et Cosmochimica Acta 62, 665-676.

Ludwig, K., 2008. User's Manual for Isoplot 3.6: A Geochronological Toolkit for Microsoft Excel, Berkeley Geochronology Centre Special Publication No.4 (78pp).

Mark, C., Cogné, N., Chew, D., 2016. Tracking exhumation and drainage divide migration of the Western Alps: a test of the apatite U-Pb thermochronometer as a detrital provenance tool. Geological Society of America Bulletin 128, 1439-1460.

Matte, P., 2001. The Variscan collage and orogeny (480-290 Ma) and the tectonic definition of the Armorica microplate: a review. Terra Nova 13, 122-128.

McAteer, C.A., Daly, J.S., Flowerdew, M.J., Whitehouse, M.J., Kirkland, C.L., 2010. A Laurentian provenance for the Dalradian rocks of north Mayo, Ireland, and evidence for an original basement-cover contact with the underlying Annagh Gneiss Complex. Journal of the Geological Society 167, 1033-1048.

Mezger, K., Krogstad, E., 1997. Interpretation of discordant U-Pb zircon ages: an evaluation. Journal of Metamorphic Geology 15, 127-140.

Nemchin, A.A., Cawood, P.A., 2005. Discordance of the U-Pb system in detrital zircons: implication for provenance studies of sedimentary rocks. Sedimentary Geology 182 143-162.

Nemchin, A., Pidgeon, R., 1997. Evolution of the darling range batholith, Yilgarn craton, western Australia: a SHRIMP zircon study. Journal of Petrology 38, 625-649.

O'Sullivan, G.J., Chew, D.M., Samson, S.D., 2016. Detecting magma-poor orogens in the detrital record. Geology 44, 871-874.

Paton, C., Hellstrom, J., Paul, B., Woodhead, J., Hergt, J., 2011. Iolite: freeware for the visualisation and processing of mass spectrometric data. Journal of Analytical Atomic Spectrometry 26, 2508-2518.

Pearce, N.J., Perkins, W.T., Westgate, J.A., Gorton, M.P., Jackson, S.E., Neal, C.R., Chenery S.P., 1997. A compilation of new and published major and trace element data for NIST SRM 610 and NIST SRM 612 glass reference materials. Geostandards and Geoanalytical Research 21, 115-144.

Petrus, J.A., Kamber, B.S., 2012. VizualAge: a novel approach to laser ablation ICP-MS U-Pb geochronology data reduction. Geostandards and Geoanalytical Research 36, 247-270.

Reimink, J.R., Davies, J.H., Waldron, J.W., Rojas, X., 2016. Dealing with discordance: a novel approach for analysing U-Pb detrital zircon datasets. Journal of the Geological Society 173, 577-585.

Rivers, T., 2015. Tectonic setting and evolution of the Grenville Orogen: an assessment of progress over the last 40 years. Geoscience Canada 42.

Schaltegger, U., Fanning, C.M., Günther, D., Maurin, J.C., Schulmann, K., Gebauer, D., 1999. Growth, annealing and recrystallization of zircon and preservation of monazite in high-grade metamorphism: conventional and in-situ U-Pb isotope, cathodoluminescence and microchemical evidence. Contributions to Mineralogy and Petrology 134, 186-201.

Schoene, B., 2014. 4.10-U-Th-Pb geochronology. Treatise on Geochemistry 341-378.

Sláma, J., Košler, J., Condon, D.J., Crowley, J.L., Gerdes, A., Hanchar, J.M., Horstwood, M.S., Morris, G.A., Nasdala, L., Norberg, N., 2008. Plešovice zircon-a new natural reference material for U-Pb and Hf isotopic microanalysis. Chemical Geology 249, 1-35.

Southgate, P., Sircombe, K.N., Lewis, C.J., 2011. New Insights into Reservoir Sand Provenance in the Exmouth Plateau and Browse Basin. APPEA Perth, Western Australia.

Spencer, C.J., Kirkland, C.L., Taylor, R.J.M., 2016. Strategies towards statistically robust interpretations of in situ U-Pb zircon geochronology. Geoscience Frontiers 7, 581-589.

Stampfli, G., Hochard, C., Vérard, C., Wilhem, C., 2013. The formation of Pangea. Tectonophysics 593, 1-19.

Tera, F., Wasserburg, G., 1972. U-Th-Pb systematics in lunar highland samples from the Luna 20 and Apollo 16 missions. Earth and Planetary Science Letters 17, 36-51.

Vavra, G., 1990. On the kinematics of zircon growth and its petrogenetic significance: a cathodoluminescence study. Contributions to Mineralogy and Petrology 106, 90-99.

Vavra, G., Gebauer, D., Schmid, R., Compston, W., 1996. Multiple zircon growth and recrystallization during polyphase Late Carboniferous to Triassic metamorphism in granulites of the Ivrea zone (Southern Alps): an ion microprobe (SHRIMP) study. Contributions to Mineralogy and Petrology 122, 337-358.

Vermeesch, P., 2012. On the visualisation of detrital age distributions. Chemical Geology 312, 190-194.

Voice, P.J., Kowalewski, M., Eriksson, K.A., 2011. Quantifying the timing and rate of crustal evolution: global compilation of radiometrically dated detrital zircon grains. The Journal of Geology 119, 109-126.

Waibel, A.F., 1993. Nature and plate-tectonic significance of orogenic magmatism in the European Alps: a review. Schweizerische Mineralogische und Petrographische Mitteilungen 73, 391-405.

Wan, Y., Song, B. Liu, D., Wilde, S.A., Wu, J. Shi, Y. Yin, X, Zhou, H., 2006. SHRIMP U-Pb zircon geochronology of Palaeoproterozoic metasedimentary rocks in the North China Craton: evidence for a major Late Palaeoproterozoic tectonothermal event. Precambrian Research 149, 249-271.

Wetherill, G.W., 1956. Discordant uranium-lead ages, I. Eos, Transactions American Geophysical Union 37, 320-326.

Whitehouse, M.J., Platt, J.P., 2003. Dating high-grade metamorphism-constraints from rare-earth elements in zircon and garnet. Contributions to Mineralogy and Petrology $145,61-74$

Wiedenbeck, M., Alle, P., Corfu, F., Griffin, W., Meier, M., Oberli, F.V., Quadt, A.V., Roddick, J., Spiegel, W., 1995. Three natural zircon standards for U-Th-Pb, Lu-Hf, trace element and REE analyses. Geostandards and Geoanalytical Research 19, 1-23.

$\mathrm{Wu}, \mathrm{Y}$., Zheng, Y., 2004. Genesis of zircon and its constraints on interpretation of U-Pb age. Chinese Science Bulletin 49, 1554-1569.

Zhang, L., Ai, Y., Li, X., Rubatto, D., Song, B., Williams, S., Song, S., Ellis, D., Liou, J., 2007. Triassic collision of western Tianshan orogenic belt, China: evidence from SHRIMP $\mathrm{U}-\mathrm{Pb}$ dating of zircon from HP/UHP eclogitic rocks. Lithos 96, 266-280.

Zimmermann, S., Hall, R., 2016. Provenance of Triassic and Jurassic sandstones in the Banda arc: petrography, heavy minerals and zircon geochronology. Gondwana Research 37, 1-19.

Zimmermann, U., Andersen, T., Madland, M.V., Larsen, I.S., 2015. The role of U-Pb ages of detrital zircons in sedimentology-an alarming case study for the impact of sampling for provenance interpretation. Sedimentary Geology 320, 38-50. 